\title{
Partial Replacement of Spent Foundry Sand in Bituminous Mix Design
}

\author{
Gazi Mohammad Harun-Or-Rashid, Abdullah Al-Mamun, Ishfaq Eashir Epu \\ Department of Civil Engineering, Rajshahi University of Engineering \& Technology, Rajshahi, Bangladesh \\ Email address: \\ gmharun.ruet11@gmail.com (G. M. Harun-Or-Rashid), abdullahasiya117@gmail.com (Abdullah-Al-Mamun), \\ epu130055@gmail.com (I. E. Epu)
}

\section{To cite this article:}

Gazi Mohammad Harun-Or-Rashid, Abdullah Al-Mamun, Ishfaq Eashir Epu. Partial Replacement of Spent Foundry Sand in Bituminous Mix Design. American Journal of Traffic and Transportation Engineering. Vol. 5, No. 3, 2020, pp. 29-33. doi: 10.11648/j.ajtte.20200503.11

Received: May 1, 2020; Accepted: June 19, 2020; Published: August 5, 2020

\begin{abstract}
Bituminous mixes for flexible pavement construction are most commonly used all over the world. Mainly aggregate, sand, bitumen etc. are used for pavement construction. In this investigation an attempt is made to study the properties of bituminous pavement materials by the partial replacement of spent foundry sand as fine aggregate with an increment of $10 \%$. Foundry sand is a high quality silica sand that is used to form molds for ferrous (iron and steel) and nonferrous (copper, aluminum, brass etc.) metal castings. Metal casting industries use huge quantity of foundry sand every year and disposed them after being used. This industrial waste occupies large amount of space of the land. If this sand can be utilized in pavement construction, the disposal and pollution problem can be minimized. The main objective of this study is to determine sufficient bitumen content and mix stability to ensure a durable and cost effective pavement after being partial replacement of foundry sand. The proposed mix design will be conducted in accordance with Marshall Mix design. After performing the experimental investigation it is found that for $30 \%$ replacement of waste foundry sand provide superior field performance and better stability than the conventional mixes.
\end{abstract}

Keywords: Flexible Pavement, Waste Foundry Sand, Marshall Mix Design, Marshall Stability and Cost Effective

\section{Introduction}

In today's world, industrial wastes have been utilized in road construction [8]. Among these wastes, foundry sand is one which can be used in road construction. Used-foundry sand is a by-product of ferrous and nonferrous metal casting industries. Foundries successfully recycle and reuse the sand many times [5]. When the sand can no longer be reused in the foundry, it is removed from the foundry and is termed as "used foundry sand". About 100 million tons of foundry sand is used by metal casting industries for production and 9 to 10 million tons of sand is discarded each year. By recycling of foundry sand can save the energy, reduce the excess pressure on virgin materials and also reduce costs [3].

In general most of the roads in Bangladesh are bituminous road. The National Highways are the backbone of the land transportation system of Bangladesh. In this sector the People's Republic of Bangladesh is very much concerned about both its stability and disruption free service throughout the year. Hot mix asphalt are widely used in pavement construction. The mix performance is determined by the properties of bitumen and also it depends on other materials used in hot mix Asphalt. In this study an attempt has to be made to find out the optimum percentage of replacement of foundry sand as fine aggregate which would be safe and cost effective.

As in the present era Used Foundry sand management is a very common and important term many studies have been conducted. In a study it was represented that by replacing some percentages like $0,25,30,35,40,75$ with foundry sand to prepare bituminous mold and the Marshall Stability test has been carried out to find out optimum percentage of foundry sand and bitumen. And the results shows that foundry sand has satisfactory improvement on bituminous concrete mix [9]. In another study it shows that the concrete with foundry sand is capable to resist the winter conditions better than any other materials suitable for pavement construction [3]. In this paper, it is proposed that the environmental effects and disposal problems can be reduced by using foundry sand in pavement construction and cost is 
also reduced [2]. Hariharan K et al., 2018 also represented that the partial replacement of $15 \%$ Quarry dust with waste foundry sand can be used as a good alternative for aggregate [6]. Sravani T et al., 2018 denoted that $40 \%$ replacement of Waste Foundry Sand for 28 days give satisfactory results in case of compressive strength as well as tensile strength [11]. Bakis R, et al, 2006 worked with ferrous and nonferrous waste foundry sand and reported that both are suitable for making structural grade concrete [12]. C. G. Konapure, et al., 2015 investigated with M 20 and M 30 grade concrete and found that $20 \%$ replacement of waste foundry sand for M 20 and $10 \%$ replacement of waste foundry sand for M 30 gives the better results [13]. Bekir and Aslan, 2017 showed that for optimum bitumen content Marshall Stability values significantly increases with waste foundry sand addition in the mixture replace of mineral aggregate [4]. Waste foundry sand is also used for low cost concrete as a partial replacement. 20 percent replacement was provided better result in an experiment [14]. In an another experiment it was found that 30 percent replacement gives satisfactory result [15].

\section{Methodology}

In this test Foundry Sand was collected from foundry shop of RUET. The appearance of the collected foundry sand and the properties of foundry sand according to Geo-structural engineering and testing services, Baroda are represented below.
Table 1. Chemical compositions of used foundry sand.

\begin{tabular}{ll}
\hline Constituents & Value (\%) \\
\hline $\mathrm{SiO}_{2}$ & 87.91 \\
$\mathrm{Al}_{2} \mathrm{O}_{3}$ & 4.70 \\
$\mathrm{Fe}_{2} \mathrm{O}_{3}$ & 0.94 \\
$\mathrm{CaO}$ & 0.14 \\
$\mathrm{MgO}$ & 0.30 \\
$\mathrm{SO}_{3}$ & 0.09 \\
$\mathrm{Na}_{2} \mathrm{O}_{3}$ & 0.19 \\
$\mathrm{~K}_{2} \mathrm{O}$ & 0.25 \\
$\mathrm{TiO}_{2}$ & 0.15 \\
$\mathrm{SrO}$ & 0.03 \\
$\mathrm{LOI}$ & 5.15 \\
\hline
\end{tabular}

Source: Geo-structural engineering and services, Baroda.

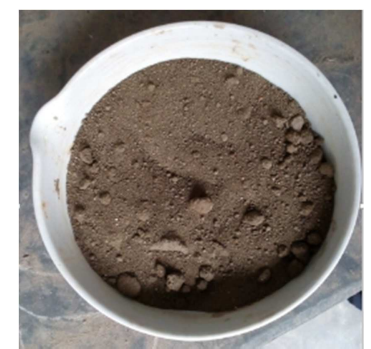

Figure 1. Physical Appearance of Foundry Sand testing.

The specific gravity of the materials used in bituminous mix were determined according to the procedure specified by AASHTO T85, T84, T133, T229 respectively and results were given in Table 1 .

Table 2. Bulk specific gravity of materials used in bituminous mix.

\begin{tabular}{llllll}
\hline Materials & CA (Crushed stone) & FA (Coarse sand) & FA (Foundry sand) & MF (Fine sand) & Binder (Bitumen) \\
\hline Specific Gravity & 2.79 & 2.46 & 2.63 & 2.60 & 1.02 \\
\hline
\end{tabular}

\subsection{Mix Design}

The objective of the study is to make a comparative study of asphalt mixes with partial replacement of fine aggregate by foundry sand in different percentages and to find out the optimum percentages of mix. Six types of mixes were studied and these were designed as mix types A, B, C, D, E and F.

Mix A: in which fresh FA is $100 \%$

Mix B: in which fresh FA is $90 \%$ and $10 \%$ foundry sand.

Mix C: in which fresh FA is $80 \%$ and $20 \%$ foundry sand.

Mix D: in which fresh FA is $70 \%$ and $30 \%$ foundry sand.

Mix E: in which fresh FA is $60 \%$ and $40 \%$ foundry sand.

Mix F: in which fresh FA is $50 \%$ and $50 \%$ foundry sand.

\subsection{Marshall Properties}

The maximum load carried by a compacted specimen at a standard test temperature of $60^{\circ} \mathrm{C}$ is defined as Marshall Stability test. The deformation of the Marshall Test specimen that undergoes during the loading upto the maximum load in $0.25 \mathrm{~mm}$ units is the flow value [10]. Hot mix design is applicable for Marshall Stability test using bitumen and aggregates. Marshall properties like stability, flow value, unit weight, total voids in a mix, voids in mineral aggregates and voids filled with bitumen were found for different percentages bitumen and Foundry Sand. The graphs were plotted for bitumen content with all the Marshall Properties. To determine the optimum bitumen content (OBC), the bitumen content corresponding to maximum stability, maximum unit weight and $4 \%$ air voids were obtained from these graphs. The optimum bitumen content $(\mathrm{OBC})$ is the average value of bitumen content obtained from the 3 plotted graphs. According to Ministry of Road Transportation Highways (MORTH), the maximum permissible air voids is 3\%-5\% [7]. Marshall Test results and $\mathrm{OBC}$ values for different percentages Foundry Sand content is tabulated in Table 3.

Table 3. Marshall Test results.

\begin{tabular}{|c|c|c|c|c|c|c|c|c|c|}
\hline Aggregate types & OBC (\%) & $\begin{array}{l}\text { Unit } \\
\left(\mathrm{kg} / \mathrm{m}^{3}\right)\end{array}$ & Wt. & $\begin{array}{l}\text { Marshall } \\
\text { stability (KN) }\end{array}$ & $\begin{array}{l}\text { Flow value } \\
(25 \mathrm{~mm})\end{array}$ & $\% \mathrm{Va}$ & \%VMA & $\%$ VFB & $\begin{array}{l}\text { Marshall Stiffness } \\
(\mathrm{KN} / \mathbf{m m})\end{array}$ \\
\hline A & 5.44 & 2343 & & 15.5 & 15.7 & 3.8 & 13.86 & 72 & 3.95 \\
\hline B & 5.5 & 2344 & & 16 & 14.75 & 4.0 & 14.75 & 74 & 4.34 \\
\hline
\end{tabular}




\begin{tabular}{llllllllll}
\hline Aggregate types & OBC (\%) & $\begin{array}{l}\text { Unit } \\
\left(\mathbf{k g} / \mathbf{m}^{\mathbf{3}}\right.\end{array}$ & $\mathbf{W t .}$ & $\begin{array}{l}\text { Marshall } \\
\text { stability }(\mathbf{K N})\end{array}$ & $\begin{array}{l}\text { Flow value } \\
\mathbf{( 2 5 m m})\end{array}$ & \%Va & \%VMA & \%VFB & $\begin{array}{l}\text { Marshall Stiffness } \\
(\mathbf{K N} / \mathbf{m m})\end{array}$ \\
\hline C & 5.51 & 2350 & 16.4 & 14.58 & 4.0 & 15.1 & 75 & 4.43 \\
D & 5.53 & 2357 & 16.7 & 13.9 & 3.9 & 15.45 & 76 & 4.48 \\
E & 5.57 & 2352 & 14.3 & 13.7 & 4.2 & 14.9 & 72 & 4.17 \\
F & 5.67 & 2338 & 13.45 & 13.4 & 4.5 & 15.5 & 71 & 4.01 \\
\hline
\end{tabular}

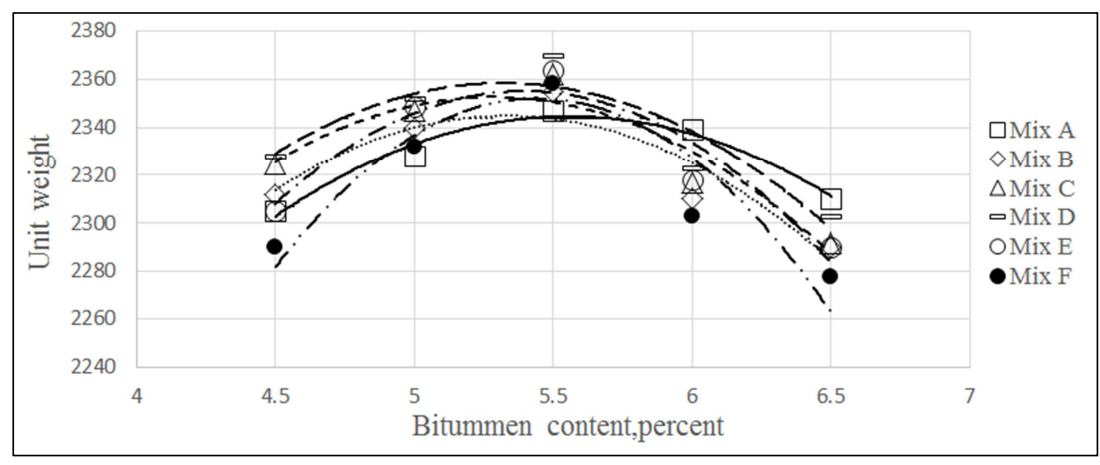

Figure 2. Relationship between Unit weight and percent bitumen content for different mixes.

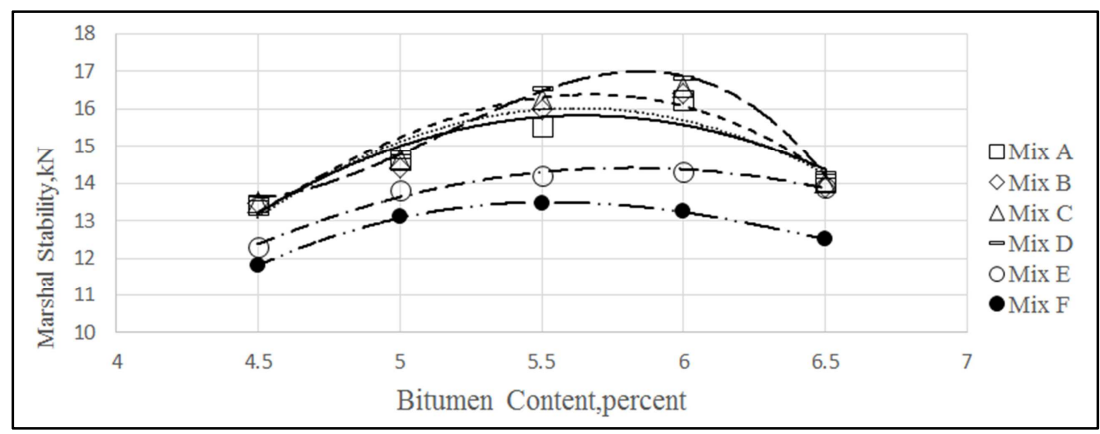

Figure 3. Relationship between Marshall Stability and percent bitumen content for different mixes.

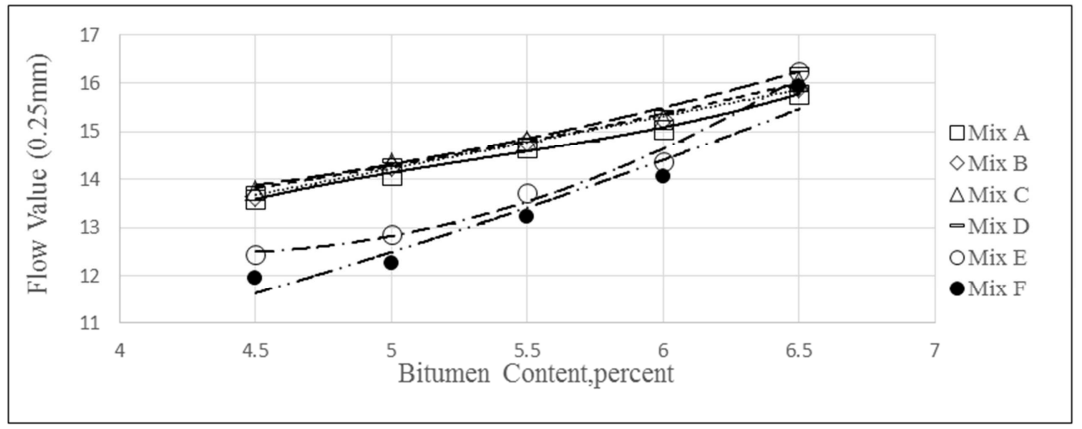

Figure 4. Relationship between Flow Value and percent bitumen content for different mixes.

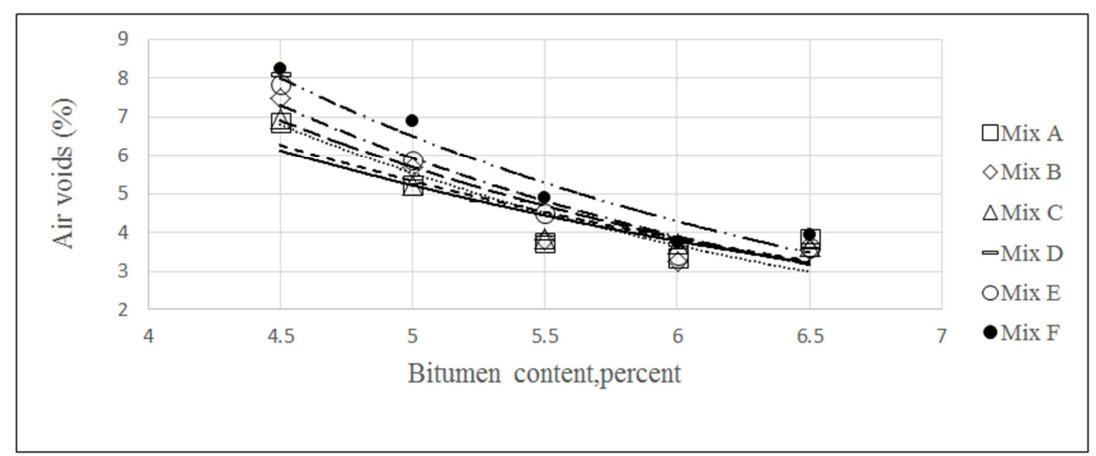

Figure 5. Relationship between Air voids and percent bitumen content for different mixes. 


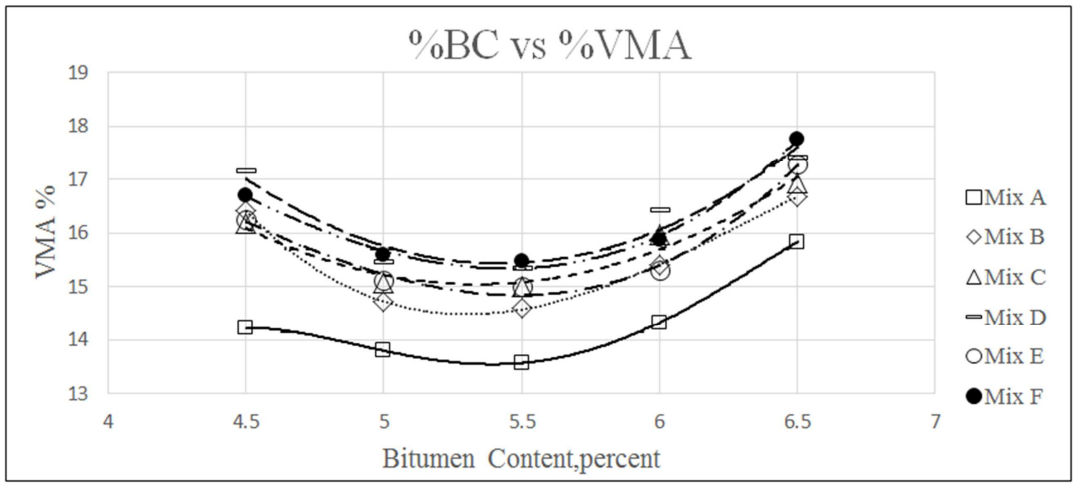

Figure 6. Relationship between\%VMA and percent bitumen content for different mixes.

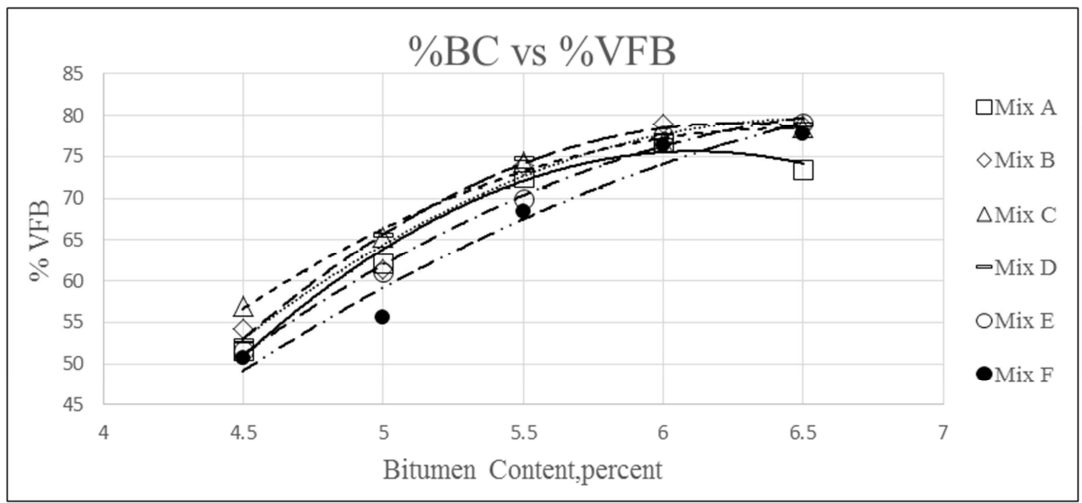

Figure 7. Relationship between $\% V F B$ and percent bitumen content for different mixes.

\section{Results and Discussions}

Generally for Hot Mix Asphalt design fine sand is used as fine aggregate whereas in this experiment waste foundry sand is used as fine aggregate as the property of this two aggregates are almost same. The obtained specific gravity of this two materials are very near. From the Marshall Test results it is seen that with the increasing percentages of foundry sand $\mathrm{OBC}$ gradually decreases. This actually happens due to the fineness of the foundry sand. From the results it is observed that for $50 \%$ replacement of foundry sand OBC value increases only $4 \%$.

Unit weight and Marshall Stability value increases with the increasing percentage of foundry sand upto $30 \%$ and then decrease. From, table 3 it is found that for $30 \%$ replacement of foundry sand, unit weight is increased a negligible amount but the stability value increase about 7\%. This happens due to the inherent binding capacity of the foundry sand. The mix flow decreases as the foundry sand percent increases. When foundry sand percent increases from zero to $50 \%$, the flow value decreases from 15.7 ( $0.01 \mathrm{inch})$ to 13.4 (0.01 inch).

Another important parameter is the air void that must be considered when designing bituminous Concrete mixture. For flexible pavement design generally the limiting value of air void is about $3 \%$ to $5 \%$ of the total mix volume. From the table 3 it is seen that increasing the foundry sand percent for all cases the percentage air voids remain within the limiting range $\% \mathrm{VMA}$ and $\% \mathrm{VFB}$ are also within the limiting range for the all percentage replacement of foundry sand. The limiting value is given by the Asphalt Institute, 1997. For the increasing percentages of foundry sand Marshall Stiffness gradually increases because Marshall Stability value gradually increases and flow value decreases gradually.

\section{Conclusions}

Waste Foundry Sand is really a suitable decision for bituminous mixes from the consideration of aggregate properties and in order to save our demandable natural resources. After careful experimental observation it is found that $30 \%$ replacement of waste foundry sand is recommended for flexible pavement design, which will be more efficient for bituminous pavement construction.

\section{References}

[1] AASHTO. "American Association for State Highway and Transportation Officials" Revised version 13-02-2015.

[2] Aravind K; Dash A. Industrial Waste in Highway Construction. pp 1-4.

[3] Benson, HC and Bradshaw, S. User Guideline For Foundry Sand In Green Infrastructure Construction. pp 1-17.

[4] Bekir, A and Sevket, A. 2017. Comparative Evaluation of Replacement Foundry Sand With Mineral Fine Aggregates on HMA Properties. Volume 7, Issue 3- July 2017, www.tojsat.net. 
[5] Chaudhari, AG; Patekar, PS; Khan, JK; Rokade, VJ and Siddiqui, AS. 2017. Review Study: On Replacement of Fine Aggregate by Foundry Sand In A Pavement. Vol. No. 3, Issue 03, March 2017- Available at www.ijirse.com.

[6] Harihan, K; Kannabiran, E; Karthik, AR and Kumar, AP. 2018. Experimental Study Of Partial Replacement Of Aggregate By Waste Foundry Sand In Flexible Pavement. Special Issue ICETSST- April 2018, www.internationaljournalssrg.org.

[7] MORTH. "Ministry of Road Transportation Highways", 5th edition, page 178 .

[8] Shinde, SS; Sayaad, AM; Bhalodia, AB; Bhasme, AR; Jadhav, VG and Hodage, VD. 2018. Use of Waste Foundry Sand in Flexible pavement. Volume 6 Issue III, March 2018- Available at www.ijraset.com.

[9] Suji D; Poovendran S and Prabhakar P. 2016. Environmental Study on Partial Replacement Of Waste Foundry Sand in Flexible Pavement, International Journal of Civil and Structural Engineering Research, vol. 4, Issue 1, Month: April 2016, pp: (188-197).

[10] Tambake, SO; Kumar, DN; and Manjunath, KR. 2014. Laboratory investigation on hot mix asphalt using reclaimed asphalt pavement for bituminous concrete mix, International Journal of Research in Engineering and Technology, Volume 03, Issue 06, Jun-2014.
[11] Sravani T; Anusha G and Mallika D. 2018. Experimental Study on Partial Replacement of Fine Aggregate with Waste Foundry Sand in Concrete. Journal of Civil Engineering and Environmental Technology, Volume 5, Issue 8; OctoberDecember, 2018, pp. 571-575

[12] Bakis R, Koyuncu H and Demirbas A. 2006. "An Investigation of Waste foundry sand in Asphalt Concrete Mixtures", Waste Management Research (WMR), e-ISSN: 2395, Issue: 3, Volume -24, PP: 269-274, (2006)

[13] Konapure C. G, and Ghanate D. G. 2015. "Effect of Industrial Waste Foundry Sand as Fine Aggregate on Concrete", International Journal of Current Engineering and Technology (IJCET), EISSN 2277 - 4106, P-ISSN 2347-5161, Issue: 4, Volume-5, PP: 2782-2786, August (2015).

[14] Pandey P, Harison A and Srivastava V. 2015. "Utilization of Waste Foundry Sand as Partial Replacement of Fine Aggregate for Low Cost Concrete", International Journal of Current Engineering and Technology, Vol. 5, No. 6 (Dec 2015)

[15] Raval A. D, Pamnani A, Kachwala A. I. 2015. "Foundry sand: utilisation as a partial replacement of fine Aggregate for establishing sustainable concrete", International Journal Of Engineering Sciences \& Research Technology, January, 2015 